\title{
IDENTIFICATION OF FISHING GROUND FOR DEEP SEA DEMERSAL FISHES AND IT'S POSSIBILITY FOR FISHING DEVELOPMENT IN THE INDIAN OCEAN
}

\author{
Wudianto ${ }^{1)}$ and Fayakun Satria ${ }^{1)}$ \\ 1) Research Center for Capture Fisheries, Ancol-Jakarta \\ Jl. Pasir Putih I, Ancol Timur-Jakarta 14430, E-mail: rccf_office@indo.net.id \\ Received April 24-2006; Received in revised from May 5-2006; Accepted June 21-2006
}

\begin{abstract}
The topographical surveys were conducted from September $1^{\text {st }}$ to $20^{\text {th }} 2004$ at southern part of Java and from September $20^{\text {th }}$ to October $30^{\text {th }} 2004$ at the western part of Sumatera. Exact isobaths were necessary to determine the size of the area in order to identify the possible fishing ground for deep sea demersal fishes. Larger flat areas were commonly found at southern part of Java suggested less constraints to utilize trawl. The sea bed features at the western part of Sumatera were heavy rough, deep, many slopes and less of flat areas suggested there were small area available to trawl and large portion to operate possible bottom long line, and traps.
\end{abstract}

KEYWORDS: bottom topography, fishing development, southern part of Java, western part of Sumatera

\section{INTRODUCTION}

Indonesia has a huge marine waters area that reached to 5.8 million $\mathrm{km}^{2}$. The area was classified as marine waters territory for 5.8 million $\mathrm{km}^{2}$ and economic exclusive zone for 2.7 million $\mathrm{km}^{2}$. The exploitation of both pelagic and demersal fish resources in the marine waters territory was reported to reach the condition of overfished as well as pelagic fish resources in some areas in the economic exclusive zone of Indonesia. Until recently there is little information regarding the exploitation of deep sea demersal fish resources from the exclusive economic zone.

Some research on deep sea demersal fish resources have been conducted in several Indonesia marine waters territory. Firstly, in 1972 Indonesia-Korea research collaboration recorded that Solenocera spp. deep sea shrimp has been found in the Indian Ocean (Anonymous, 1975). Secondly, in 1991 KARUBAR I expedition noted 18 species of deep sea shrimps and some demersal fishes in the waters of Kai, Aru, and Tanimbar Islands (Anonymous, 1991), in 1993 the expedition of KARUBAR II in the waters of Kai, Aru, and Tanimbar Islands informed stock density of deep sea fishes and shrimps of about 0.072 to 0.297 tonnes $\mathrm{km}^{-2}$ (Sumiono \& Iskandar, 1993) and 0.28 to 1.97 tonnes $\mathrm{km}^{-2}$ (Soselisa et al., 1993) respectively. Thirdly, in 2003 UMITAKA MARU cruise was utilized bottom otter trawl in the Indian Ocean (Purbayanto et al., 2003).

Recently, during 2004 and 2005 the Japan-Indonesia deep-sea fisheries resources joint exploration project was instituted between Indonesia's Research Institute of Marine Fisheries and Japan's Overseas Fishery
Cooperation Foundation. The objective of the survey was'to explore the unutilized fishery resource in the waters deeper than $200 \mathrm{~m}$ in the Indian Ocean off Java and Sumatera. In order to achieve the objective, the following research items were adopted i.e. Bathymetry of the area in 2004 and 2005 in order to get information on the actual depth and bottom topography of the area with echo sounder, exploratory fishing with a deep sea bottom otter trawl, biological research, and oceanography survey.

The current paper describes grafically the bathymetry of southern Java water and western Sumatera. Identification of fishing ground for deep sea fish and it is possibility for fishing development will mainly based on the plotted bathymetry data.

\section{MATERIALS AND METHODS}

The topographical survey has been conducted from September $1^{\text {st }}$ to $20^{\text {th }} 2004$ at southern part of Java (Figure 1) and from September $20^{\text {th }}$ to October $30^{\text {th }} 2004$ at the western part of Sumatera (Figure 2).

Research using R. V. Baruna Jaya IV was equipped with deep sea echo sounder with $35 \mathrm{KHz}$, shallow sea echo sounder with $200 \mathrm{KHz}$ and side scan sonar with effective range $350 \mathrm{~m}$. The research vessel was run at 10 knots along the transect lines between the designated points. In every 5 minutes of moving and at each point and also at the depth contour of $100 \mathrm{~m}$ interval, the depth at each position was recorded in a blank chart. Also, in order to calculate the sea floor areas by depth layer, bathymetry of the sea floor was carried out partially in the territorial waters. Cruise tracks for bathymetry survey are shown in Figure 1 and 2. 


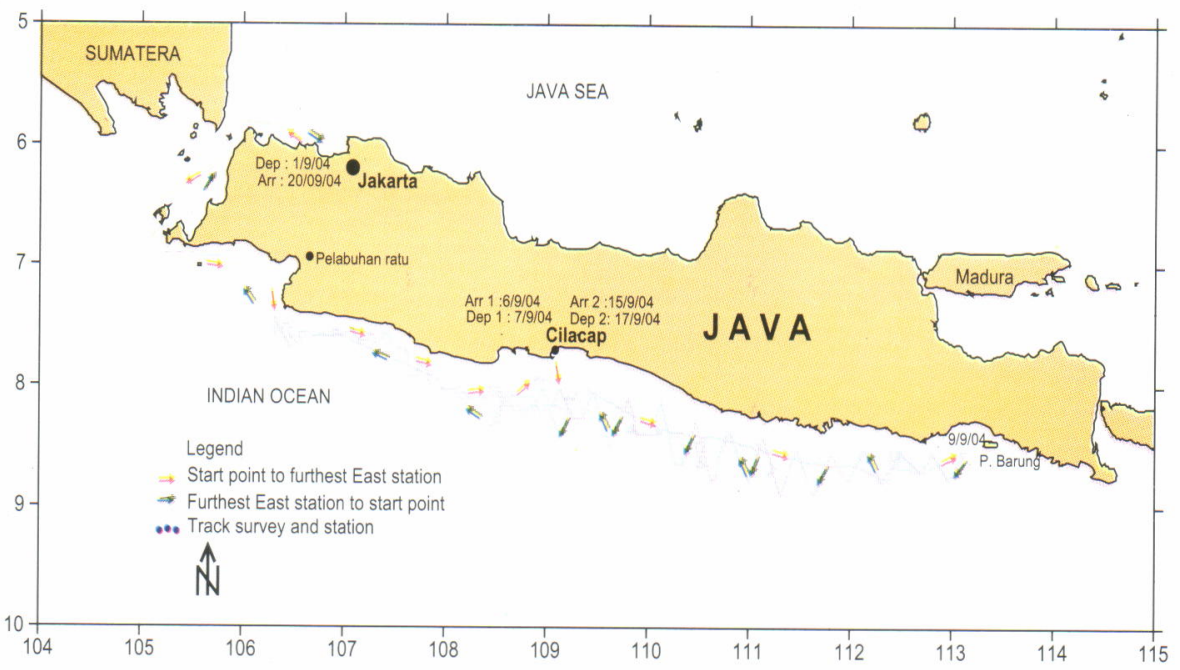

Figure 1. Cruise track in the Indian Ocean of Java, in 2004. Sources: Anonymous (2006)

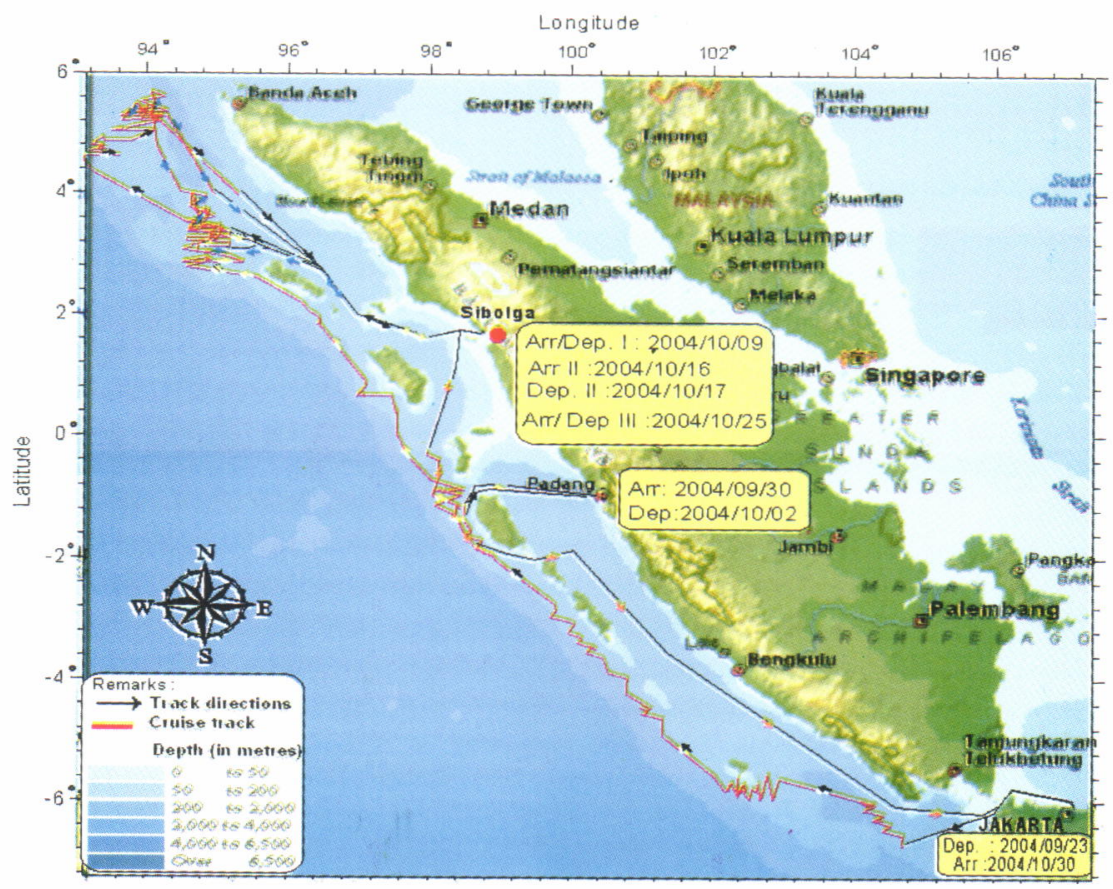

Figure 2. Cruise track in the Indian Ocean of Sumatera, in 2004. Sources: Anonymous (2006)

The bottom topography was presented in three dimensions by area and depth. 4 depth strata was classified from 200 to $1,100 \mathrm{~m}$ with increments between 200 to $500 \mathrm{~m} ; 501$ to $750 \mathrm{~m} ; 751$ to $1,100 \mathrm{~m}$; and $>1,100$ $\mathrm{m}$. Three dimensions graphs of each survey area was drawn in order to help understanding general feature of bottom topography of the area. The graphs will be utilized in determining the boundary of each depth stratum as a unit for Identification of Fishing Ground. The figure will be used for investigating the potential fishing ground for fishing the deep sea fish and what kind of fishing gears suit in the area. Trawlable fishing ground was the area that has met the condition i.e. 1) possible to make a towing of trawl for 30 minutes; 2) relatively flat that is between point no exceed than $50 \mathrm{~m}$; and 3) there is no sudden extreme slope or hill occurred. Based on the bathymery data a isobath countoured was produced. The contours were then groupped into different colors i.e. yellow, green, and blue representing trawlable area while grey and black colors for untrawlable area. The area with a similar color will presume as identification of area with a relatively similar group of depth. 


\section{RESULTS AND DISCUSSION}

\section{Identification of Fishing Ground}

Exact isobath groups were necessary to determine the size and profile of the area in order to assess the possible fishing ground. Based on bathymetry data in 2004 there were a total numbers of observation of about 8,000 points. Bathymetrical graphs of southern Java and southwestern Sumatera area were drawn in order to help understanding general feature of bottom topography of the areas as are shown as Figures 3 and 4.

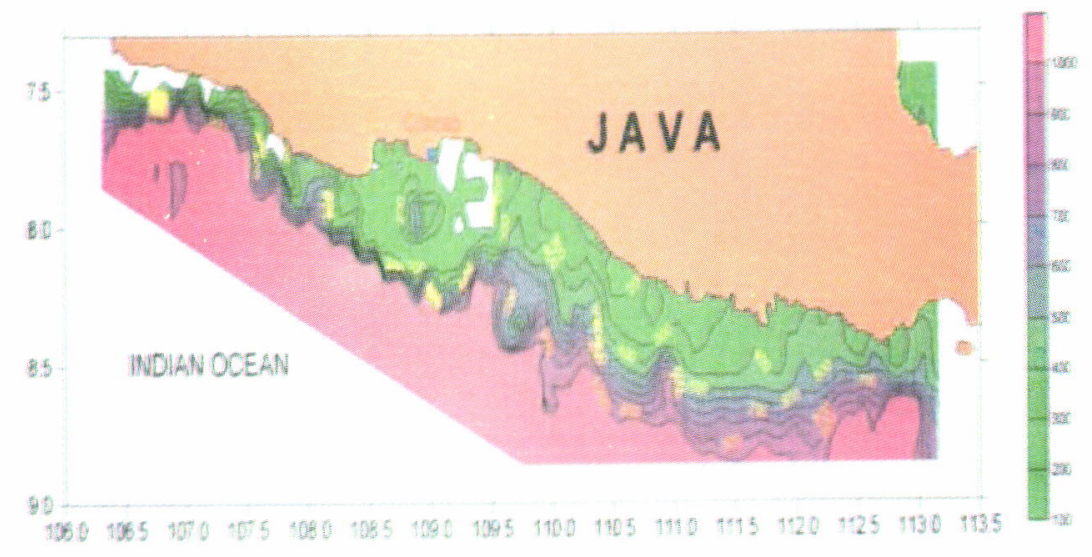

Figure 3. Depth contour of southern Java.

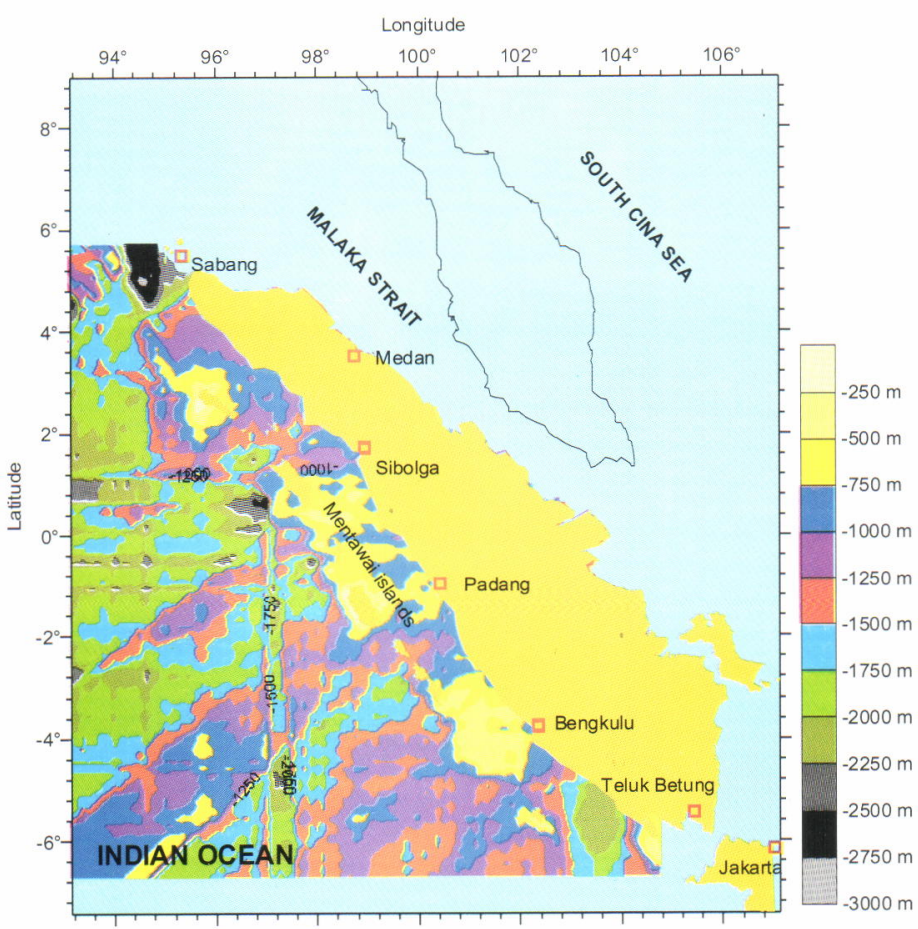

Figure 4. Depth contour of the western Sumatera.

\section{Southern of Java}

The profiles of bottom topography along south of Java waters was moderately rough. The total of surveyed area was about $148.172 \mathrm{~km}^{2}$ with variability of depths ranged from 60 to $1,470 \mathrm{~m}$. The depths were grouped into four increments i.e. 200 to $500 \mathrm{~m} ; 501$ to $750 \mathrm{~m} ; 751$ to $1,000 \mathrm{~m}$; and $>1,000 \mathrm{~m}$ and ploted into a contour map. Each of depth group was $33,515.1 \mathrm{~km}^{2}(22.6 \%) ; 44,099$ (29.8\%); $59,974.3 \mathrm{~km}^{2}(40.5 \%)$; and $10,583.7(7.1 \%)$ for depth zone of 200 to $500 \mathrm{~m} ; 501$ to $750 \mathrm{~m} ; 751$ to 1,000 $\mathrm{m}$, and $>1,000 \mathrm{~m}$ respectively (Figure 5 and 6 ). 


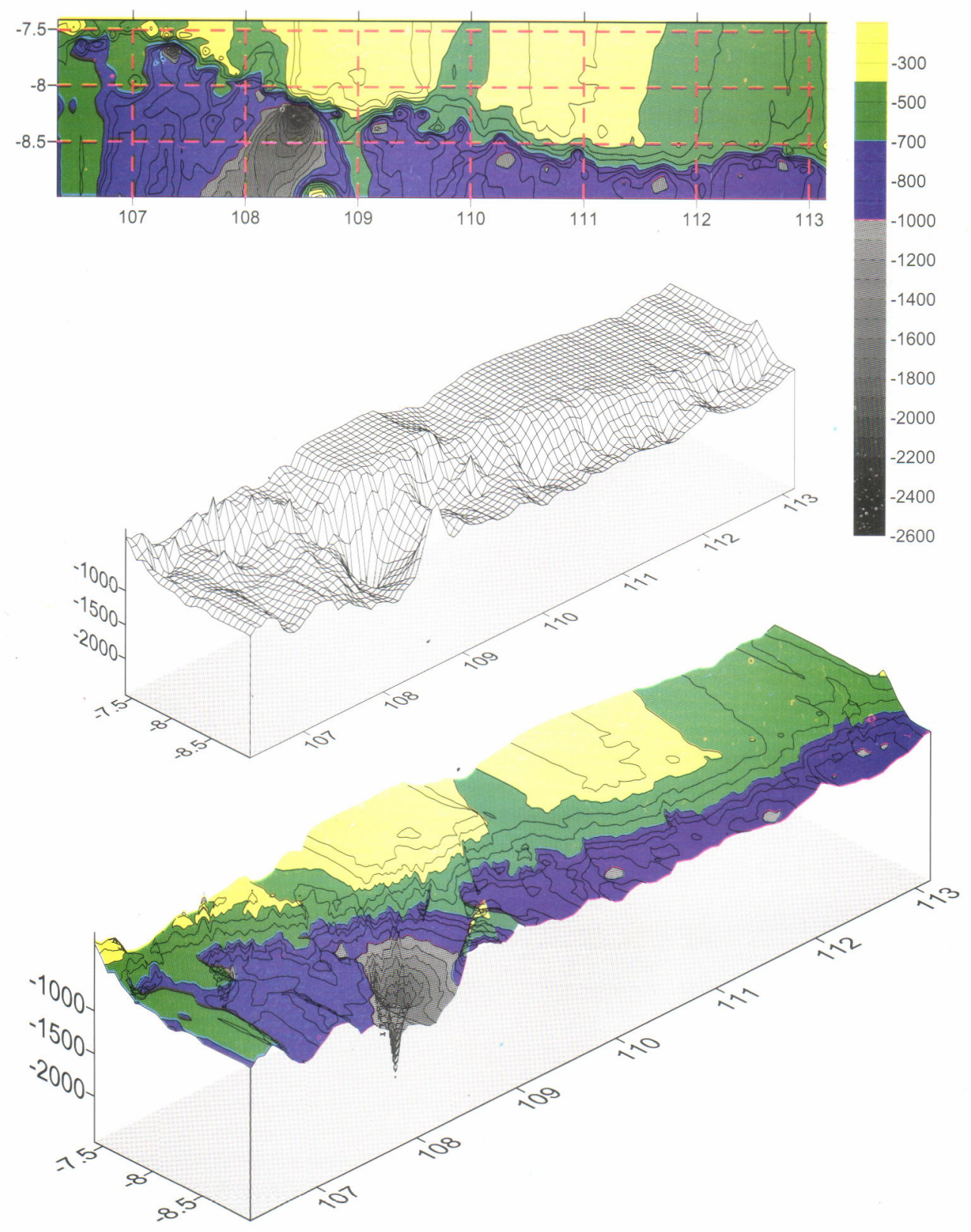

Figure 5. Bathymetrical map of the sea floor in the Indian Ocean off Java. 


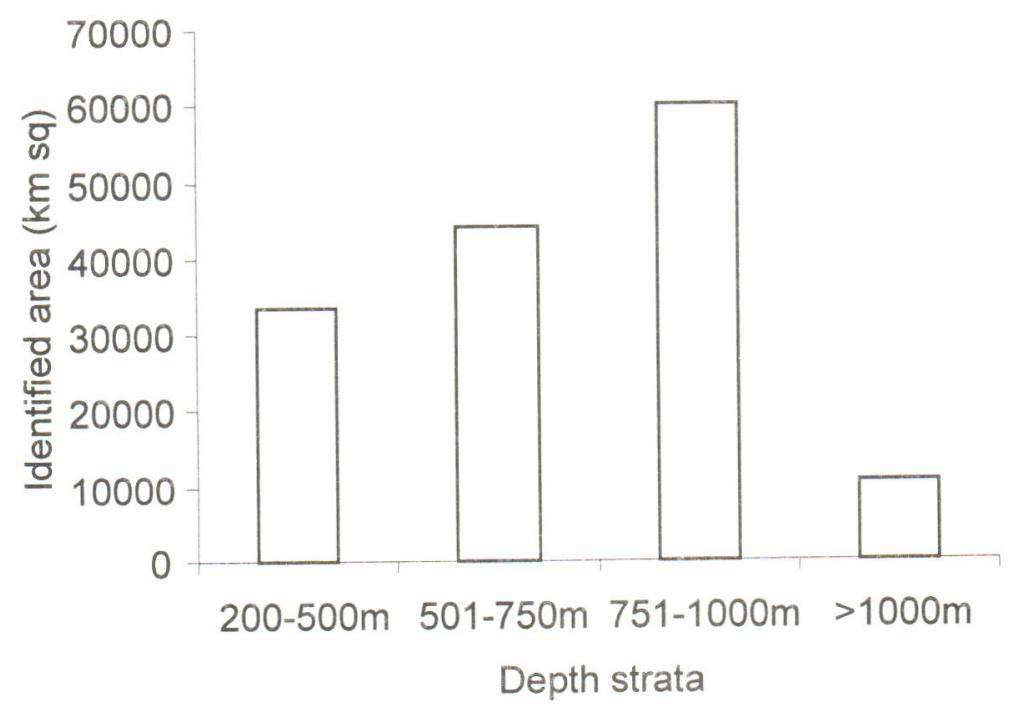

Figure 6. The estimated of isobath area of each depth groups in the Indian Ocean of Java.

Deep sea bottom trawl was the most effective fishing gear to catch demersal fishes but potentially to risk safety on the gear and vessel. Carefull identification of sea bed features prior to the fishing operation is a must. Other fishing gears such as pot or trap, and bottom long line were also possible to be operated in both trawlable and untrawlable area.

\section{Western of Sumatera}

The features of bottom topography along the western of Sumatera waters has typical characteristics i.e. heavy rough, deep, many slopes, and few flat area. The area covered was about $1,778,062 \mathrm{~km}^{2}$ with variability of depths ranged from 50 to $3,212 \mathrm{~m}$. The depths were grouped into four depth zones i.e. 200 to $500 \mathrm{~m} ; 501$ to $750 \mathrm{~m} ; 751$ to $1,000 \mathrm{~m}$; and $>1,000 \mathrm{~m}$. Each groups gave about $24,695.3 \mathrm{~km}^{2}(1.4 \%) ; 185,214.8(10.4 \%)$; $382,777.3 \mathrm{~km}^{2}(21.5 \%)$; and $1,185,375(66.7 \%)$ for depth range of 200 to $500 \mathrm{~m} ; 500$ to $750 \mathrm{~m} ; 750$ to $1,000 \mathrm{~m}$; and $>1,000$ m respectively (Figure 8 ).

The depth of the western Sumatera waters generally greater than $1,000 \mathrm{~m}$. Possible fishing gears to develop in this area were pots, traps, and bottom long line.

\section{Possibility for Fishing Development}

\section{Trawl Fishing Gear}

Flat bottom fishing ground was mainly atributed in the area of southern Java waters of Indian Ocean. In this types of seabed the fishing ground was possible to utilize many fishing gears such as trawl, pots, and bottom long line.

There are two types of trawl that possible to operate in the field i.e. otter trawl and beam trawl. The main difference of these two gears is laid on the mouth opening. Otter trawl mouth opening's are using a pair of otter boards installed on the edge of net connected by briedel line, while the mouth opening's of beam trawl are using bar logg installed on the edge of net mouth's (Subani \& Barus, 1989). It was reported that both beam trawl and otter trawl were very effective gears to catch deep sea fishes and shrimps in the waters of. Kai and Tanimbar islands (Wudianto \& Barus, 1993; Linting \& Rahardjo, 1993).

Trawl net cannot be operated and handled in the area with roughed, bumped, or rocked sea bed. The waters along southern of Java has many area with large flat sea bed features, particulariy those with yellow color. Narow area extended from $106^{\circ}$ to $108^{\circ} \mathrm{E}$ still possible to use the gear with a carefull operation (Figure 5). In the western of Sumatera there was narrow flat sea bed with depth ranged 200 to $500 \mathrm{~m}$ (Figure 7). Wider flat sea bed were mostly found in the deeper zone of 700 to $1,000 \mathrm{~m}$ (blue area). These will bring more consequencies in the form of effort, time, and cost to exploit the resources. For instances we need longer warp and more powerful engine to fish. Eventhough the trawlable area was very narrow (Figure 7). 

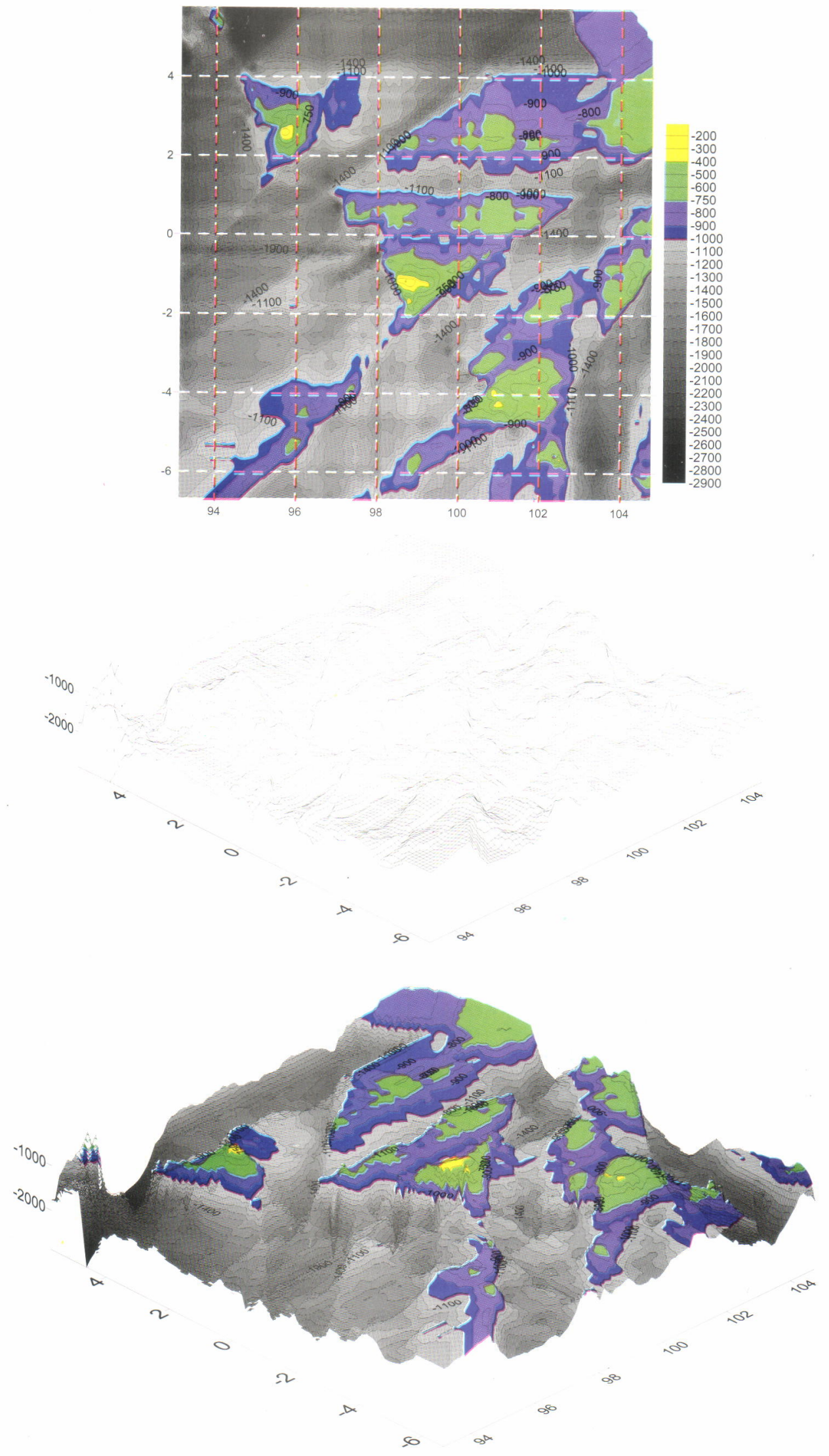

Figure 7. Bathymetrical map of the sea floor in the Indian Ocean of Sumatera. 


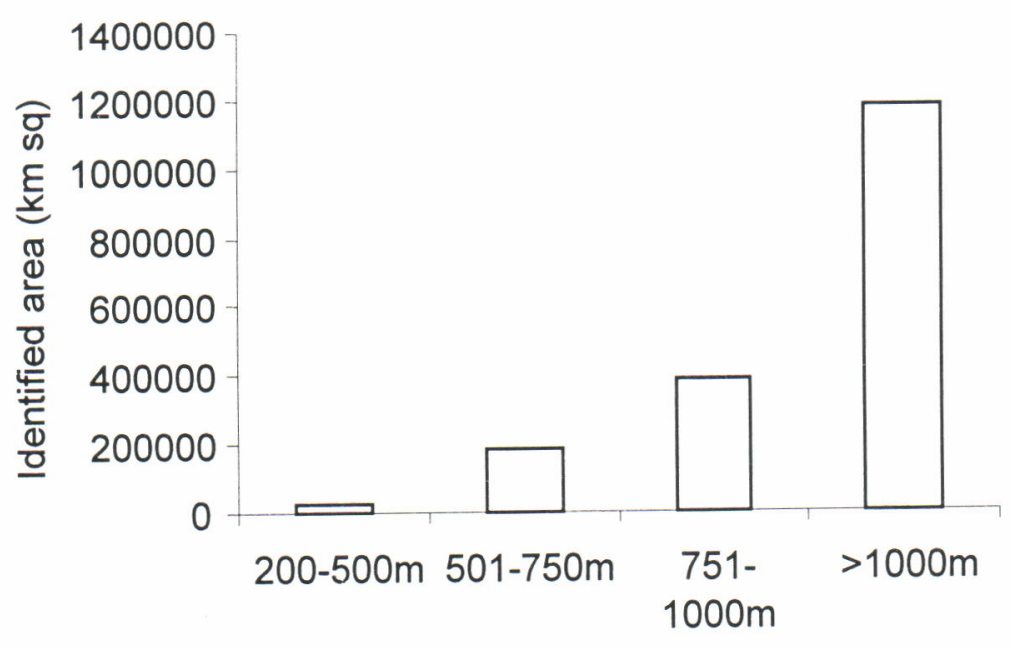

Depth strata

Figure 8. The estimated of isobath area of each depth groups in the Indian Ocean of Sumatera.

The operation of otter trawl, will need a relatively wide of flat sea bed while beam trawl is still possible to operate on the lesser flat sea bed. This is due to the mouth opening of the otter trawl is bigger than beam trawl. (Figure 9 and 10).

\section{Traps or Pots Fishing Gear}

Pots fishing gear not only easy to handle but also possible to place on any kind of sea bed. It is possible to deploy this fishing gear in the area with less of flat area, rubble, or moderately rough sea bed (Amin et al., 1993). Compare to trawl, pots fishing operation is not restricted to the wide flat sea bed as trawl operation.
Deep sea pots contructed from steel as frames and monofilament (PE) webbing as walls. There were three types of pots that have been proved by experimental fishing i.e folding pots, trapezium pots, and semi cylindrical pots Figure 11. The three pots were reported to have no significant difference catch rate of deep sea shrimps (Barus \& Wudianto, 1993). Fish baits were commonly used and placed in the pots in order to attract the target to entry the pots. Rahardjo \& Linting (1993) reported that the used of scads as bait in the pots has a higher diversity of fishes and shrimps caught compared to sardine and tuna's head. While sardine gave higher of caught in term of number compare to the others. In term of soaking time, pots with 2 days of soaking time was reported caught more of srimps but less for fishes compared to 1 days of soaking times (Amin et al., 1993), but the optimum soaking time is still unknoun.

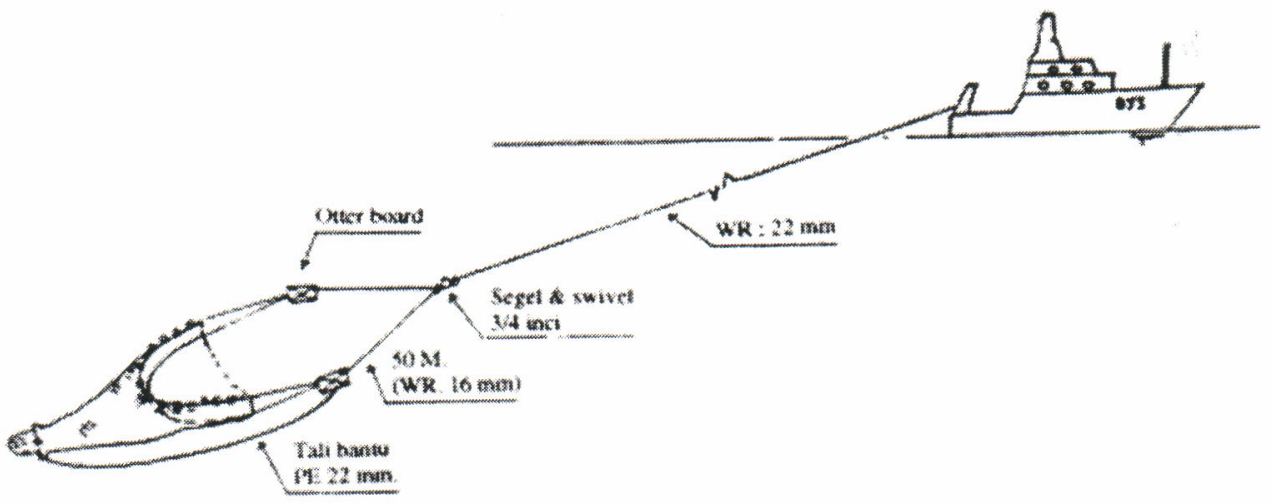

Figure 9. Design of otter trawl net during towing condition (Linting \& Raharjo, 1993). 


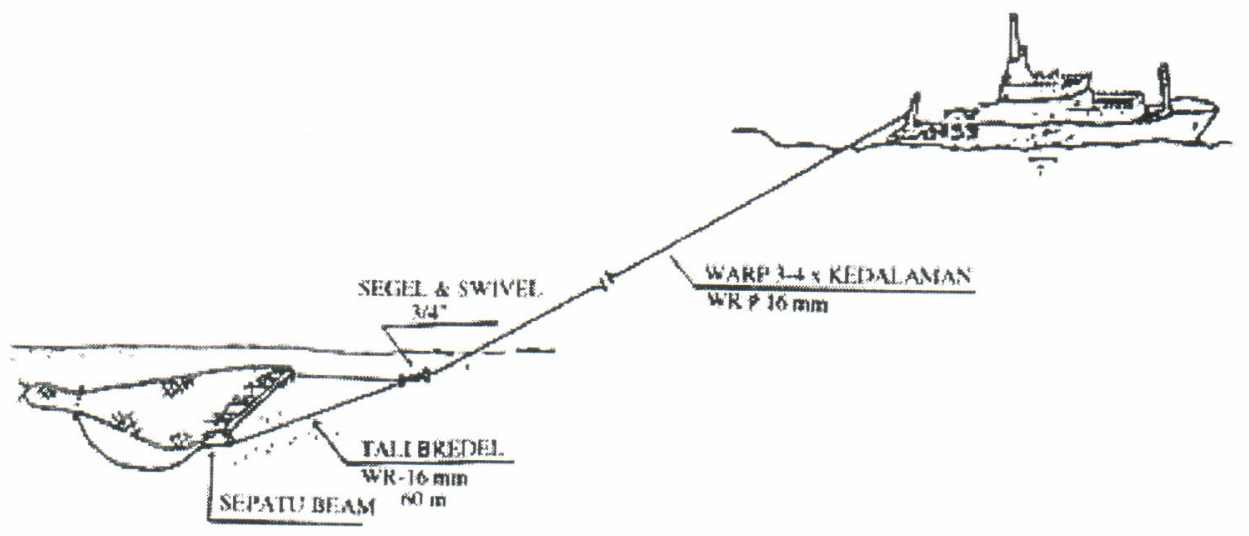

Figure 10. Operation of beam trawl at the sea. Sources: Wudianto \& Barus (1993)

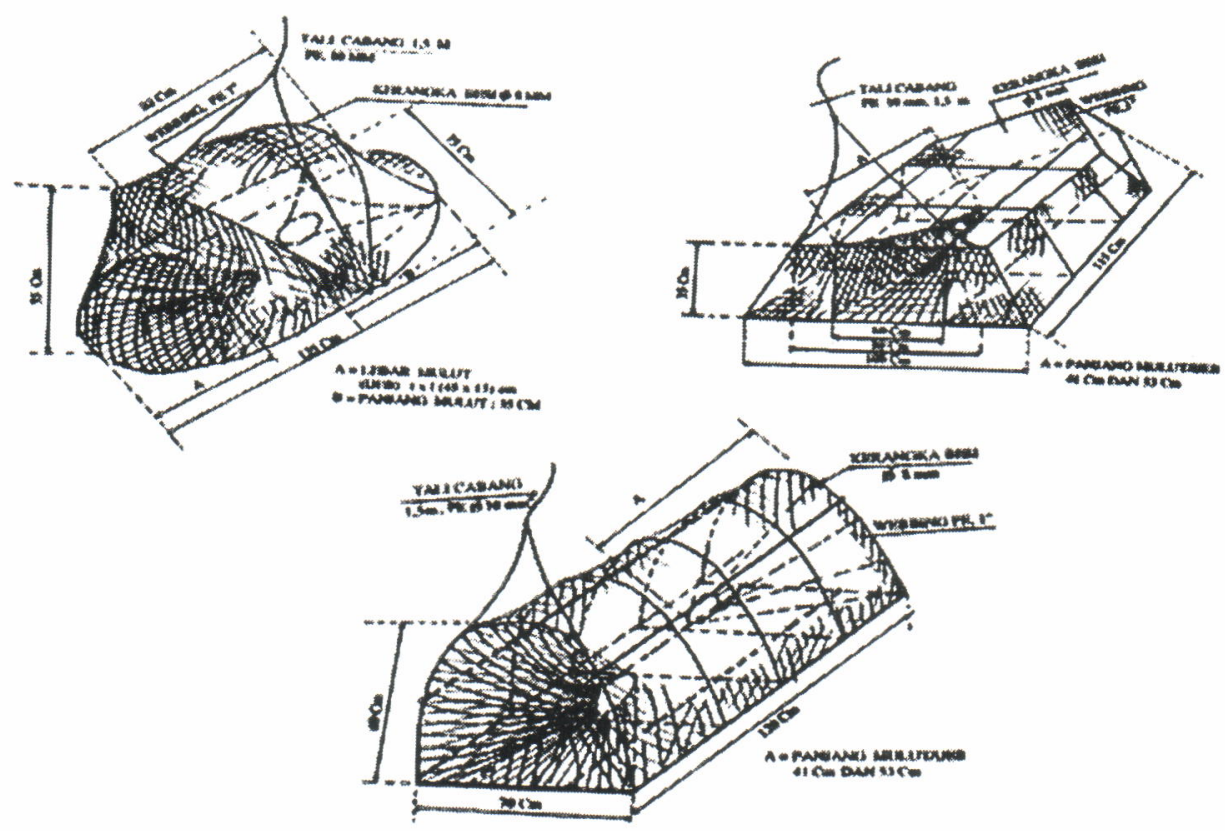

Figure 11. Three types design of pots (a) folding type, (b) trapezium type, and (c) cylindrical type.
Sources: Barus \& Wudianto (1993)

\section{Bottom Long Line Fishing Gear}

Bottom long line fishing gear has a flexible handling in term of the area of operation. It is suitable to operate on many kinds of seabed from flat area to rough rocky sea bed or steep and slope area. The fishing gear will be suitable to operate in the area of southern of Java or the western of Sumatera (Figure 13). A unit of bottom long line consists of main line, branch line, swivel, and hook (Figure 9). Experimental fishing of bottom long line was reported to be done out in the area deeper than 200 $\mathrm{m}$ (Wudianto et al. 1995; Wibowo, 2004). In the operation of bottom long line there were various baits commonly used such as sardines, scads, or slices meet of congrids. Today both salt and fresh fish baits are commonly utilized as a bait in bottom long line fishery.

Live bait was reported to have a higher catch rate compared to salt fish bait (Mahiswara \& Wudianto, 2001). 


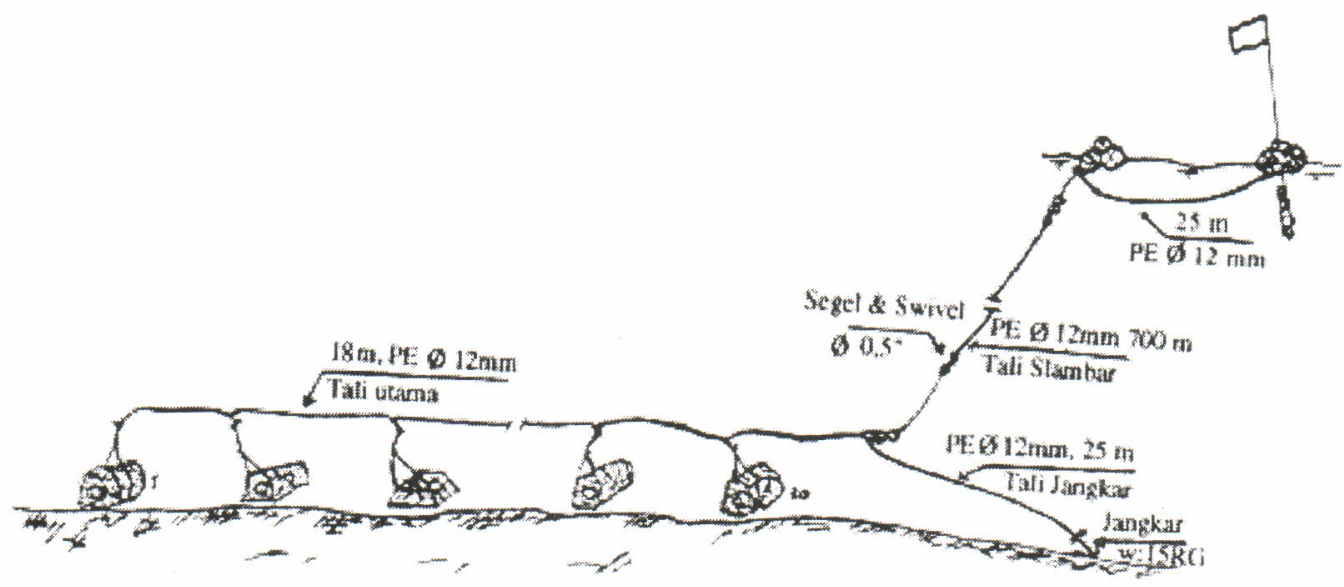

Figure 12. Configuration of traps at the bottom using long line method. Sources: Amin et al. (1993)

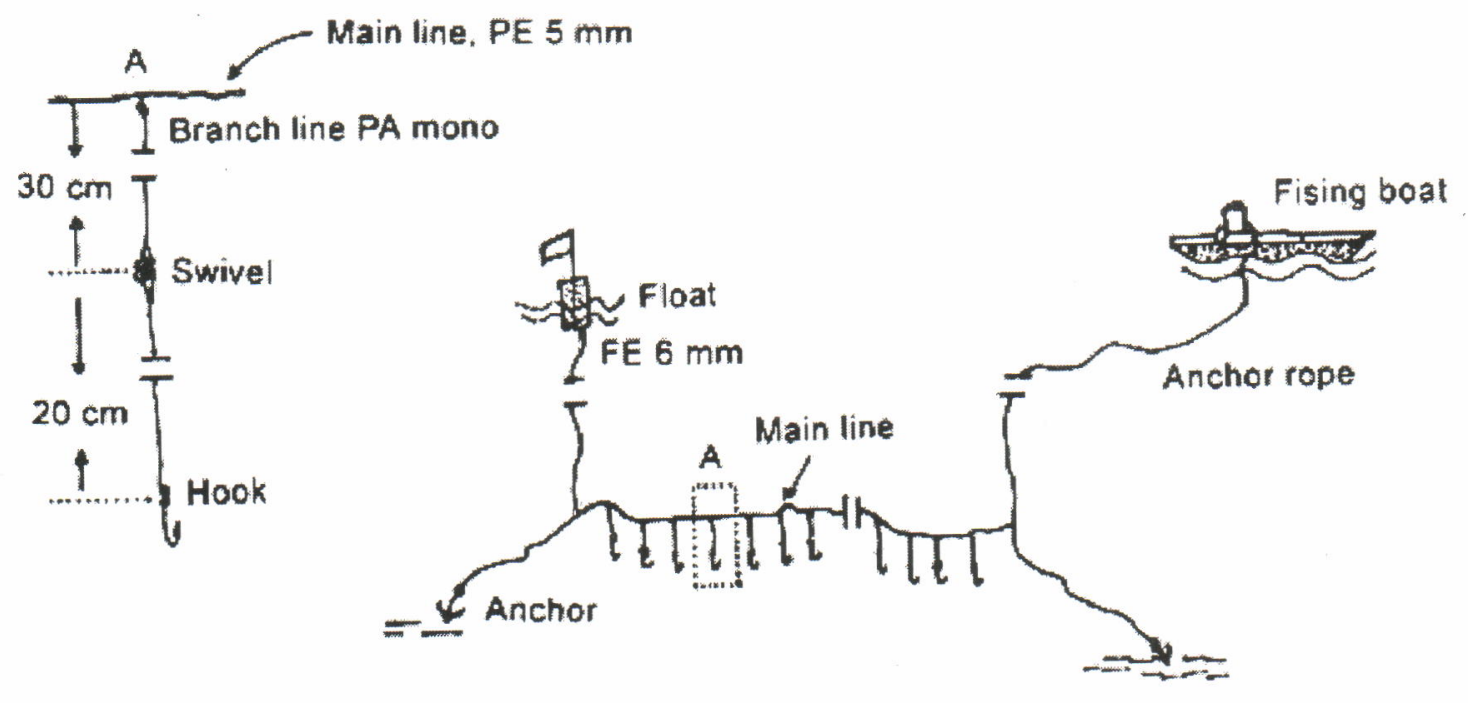

Figure 13. Design of bottom long line during operated at the sea: Sources: Wudianto et al. (1995)

\section{RECOMMENDATION}

In term of the sea bed features, there were some possible area in the Indian ocean as fishing ground for operating trawl (beam and otter). A wider flat sea floor suitable for trawl operation were found in the south of Java compare with the waters of western Sumatera. Pots, bottom long line, and traps provide some possible fishing gears to deploy at untrawlable area that's mainly located in the western of Sumatera.

\section{Acknowledgements:}

This paper is part of 'Indonesian-Japan joint program on deep sea fisheries resources' in 2005.

\section{REFERENCES}

Amin, E. M., Sudjianto, \& A. Widodo. 1993. Teknik dan daerah pengoperasian bubu laut dalam di perairan Pulau-Pulau Kai, Tanimbar, dan ZEE Selatan Timor. Jurnal Penelitian Perikanan Laut. 77 tahun 1993. 54-71.

Anonymous. 1991. Karubar expedition I. Research Institute for Marine Fisheries. Intern report.

Anonymous. 2005. The Japan-Indonesia deep sea Fishery Resources Joint Exploration Project (Report of 2004 Field Survey). Overseas Fishery Foundation-Research Institute for Marine Fisheries. (unpublised). 
Anonymous. 2006. The Japan-Indonesia deep sea fisheries resources joint exploration project (final report). Overseas Fishery Cooperation Foundation Japan-Agency for Marine and Fisheries Research. Ministry of Marine Affairs and Fisheries-Indonesia March 2006. 154 p.

Anonymous. 1975. Investigation for the unexploited fishing ground in the adjacent sea to Indonesia. Fishery Research and Development Agency. Busan. Korea. March 1975. 82 p.

Anonymous. 2003. Report on deep sea 2003, an international conference on governance and management of deep sea fisheries. FAO Fisheries Report No.772. Queenstown. New Zealand. 1-5 December 2003. 83 p.

Barus, H. R. \& Wudianto. 1993. Penelitian berbagai tipe bubu untuk penangkapan udang laut dalam. Jurnal Penelitian Perikanan Laut. 77 tahun 1993. 42-53.

Linting, M. L. \& P. Rahardjo. 1993. Otter trawl untuk penangkapan ikan dan udang laut dalam serta permasalahannya. Jurnal Penelitian Perikanan Laut. 77 tahun 1993. 82-91.

Lozac'Hmeur, J., A. Venkatasami, G. Silvestrini, S. Beeharry-Panray, \& S. Soondron. 1991. Development of deepwater shrimp fishery. Report prepared for the project development of advanced artisanal fishery for deepwater shrimp and snappers. FI:DP/MAR/88/004. Field Document December 1991. FAO. Rome. 60 p.

Mahiswara \& Wudianto. 2001. Catch differences of bottom long line using fresh and salted fish baits. Indonesian Journal of Agricultural Science. 2 (1). 27-29.
Purbayanto, A., Darmawan, \& Hestirianoto. 2003. Preliminary report. Trawl survey for deep sea fish resource in the Indian ocean, 9-24 December 2003. Faculty of Fisheries and Marine Science. Bogor Agricultural University.

Rahardjo, P. \& M. L. Linting. 1993. Penelitian jenis umpan untuk bubu laut dalam. Jurnal Penelitian Perikanan Laut. 77 tahun 1993. 72-81.

Soselisa, J., R. Rustam \& M. Badrudin. 1993. Penyebaran dan potensi sumber daya ikan laut dalam di perairan Kai, Tanimbar, dan Laut Timor. Jurnal Penelitian Perikanan Laut. 77 tahun 1993. 27-32.

Sumiono, B. \& B. Iskandar. 1993. Penyebaran dan kepadatan stok udang laut dalam di perairan Tanimbar dan Laut Timor. Jurnal Penelitian Perikanan Laut. 77 tahun 1993. 1-15.

Wibowo, B. 2004. Laporan sementara kegiatan survei laut dalam di Samudera Hindia dan Laut Arafura. Mei 2004-Juli 2004. Pusat Riset Perikanan Tangkap. Badan Riset Kelautan dan Perikanan. $12 \mathrm{p}$ (Unpublished).

Wudianto, Mahiswara, \& M. L. Linting. 1995. Pengaruh ukuran mata pancing rawai dasar terhadap hasil tangkapan. Jurnal Penelitian Perikanan Indonesia. I (1). 58-67.

Wudianto \& H. R. Barus. 1993. Penangkapan udang laut dalam dengan beam trawl. Jurnal Penelitian Perikanan Laut. 77 tahun 1993. 92-106. 